\title{
TWO NEW SPECIES OF OSTEOSPERMUM (COMPOSITAE-CALENDULEAE) FROM SOUTHWESTERN CAPE PROVINCE, SOUTH AFRICA
}

\author{
B. NORDENSTAM*
}

The tribe Calenduleae of the Compositae (Asteraceae) has a pronounced centre of diversity in South Africa, particularly in Cape Province. The largest genus, Osteospermum L., contains c.50 species in Africa and southwestern Arabia, including about 40 in Cape Province. Two new species are described here, both narrowly endemic in southwestern Cape Province. Osteospermum australe is confined to lowland coastal limestone areas in Bredasdorp district, whereas Osteospermum burttianum has a restricted distribution in the Langebergen mountains in Heidelberg district.

Keywords. Asteraceae, Calenduleae, new species, Osteospermum, South Africa, systematics.

\section{INTRODUCTION}

Ongoing studies in the small tribe Calenduleae (Compositae) suggest a number of taxonomic changes. The tribe was thoroughly studied by Tycho Norlindh (19061995); in a series of papers he presented a useful account particularly of the South African members (Norlindh, 1943, 1960, 1977). However, recent research findings, including molecular data, suggest a revised generic taxonomy (cf. Nordenstam, 1994a,b, 1996; Wood \& Nordenstam, 2003). New herbarium accessions and better field observations are also destined to modify and refine Norlindh's taxonomy at species level (Nordenstam \& Wood, in prep.). Two distinct new species of Osteospermum L. are described here.

\section{TAXONOMY AND DISCUSSION}

Osteospermum australe B. Nord., sp. nov. (sect. Polygalina DC.). Fig. 1.

Frutex erectus $0.5-1 \mathrm{~m}$ altus parce ramosus, caulis et rami dense foliati primo lana laxa albida vestiti mox glabrescentes vel ad axillas tantum lanati. Folia alterna sessilia subimbricata vel erecto-patentia integra semiamplexicaulia coriacea ellipticoovata usque oblongo-lanceolata vel rarius oblanceolata $2-5 \times 0.5-2 \mathrm{~cm}$ margine incrassato albescenti scabro; nervus medius prominens albescens scabridus. Capitula

* Department of Phanerogamic Botany, Swedish Museum of Natural History, PO Box 50007, SE-104 05 Stockholm, Sweden. E-mail: bertil.nordenstam@nrm.se 


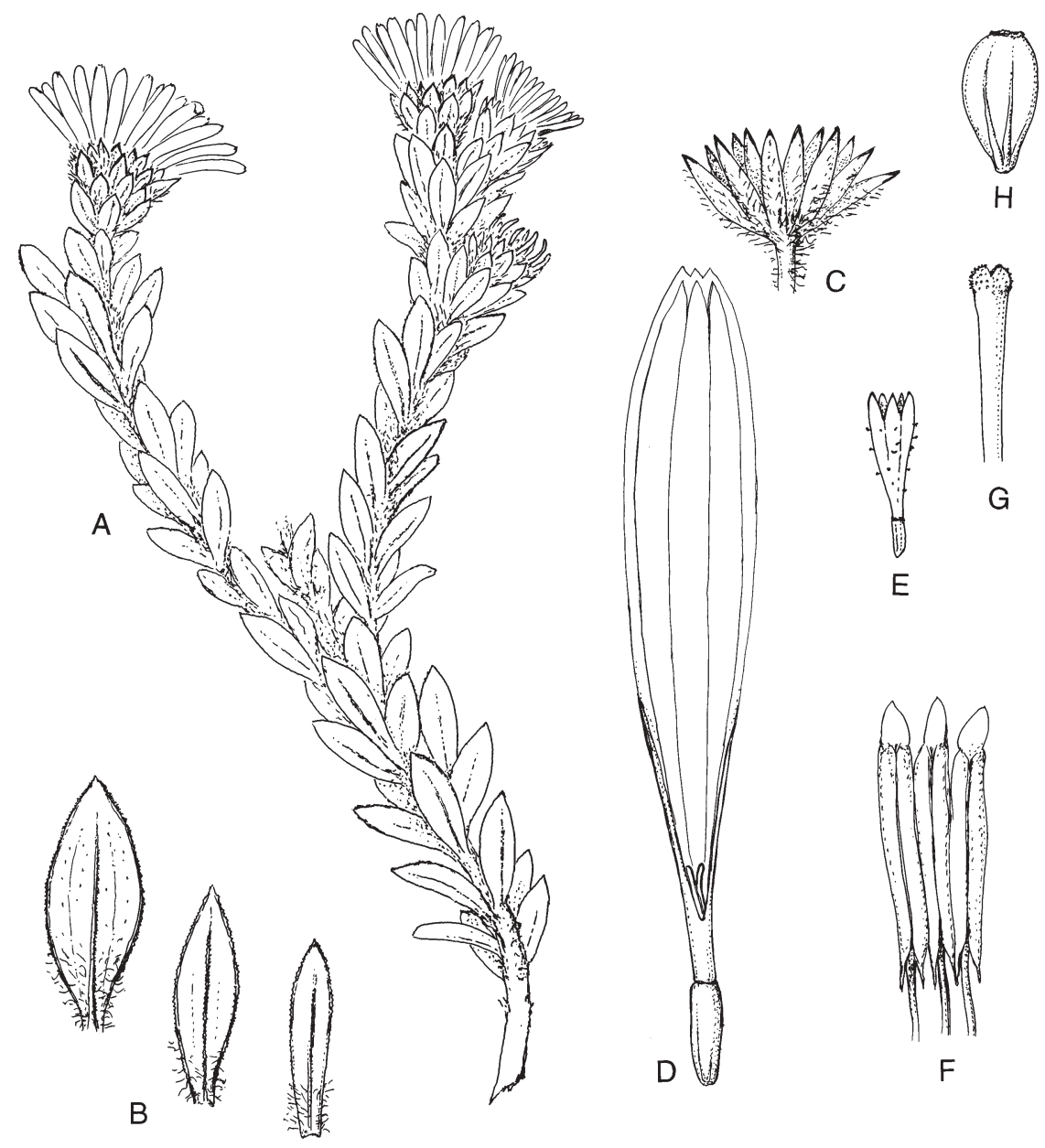

FIG. 1. Osteospermum australe. A, habit $\left(\times \frac{1}{2}\right) ; \mathrm{B}$, leaves $\left(\times^{1 / 2}\right) ; \mathrm{C}$, involucre $(\times 1) ; \mathrm{D}$, ray-flower $(\times 3)$; E, disc-flower $(\times 3)$; F, anthers $(\times 12)$; $\mathrm{G}$, style of disc-flower $(\times 12)$; $\mathrm{H}$, cypsela (×3). (A, C-H: Nordenstam 1461 in S, holotype; B: Hugo 2666 in PRE). Drawn by the author.

terminalia solitaria sessilia vel subsessilia magna radiata. Involucri squamae 14-17 circiter biseriatae anguste oblongo-lanceolatae $10-20 \times 2-5 \mathrm{~mm}$ latae apice violascentes acutae vel acuminatae dorso albolanatae. Flores radii feminei 11-20; ligulae luteae vel aurantiacae subtus rubescentes vel marroninae. Cypselae ellipsoideoobovoideae $5-5.5 \times 3 \mathrm{~mm}$ glabrae fuscae vel stramineae obscure costatae. Flores disci numerosi pseudohermaphroditi o-steriles: corolla flava quinquelobata sparse glandulosa. Antherae breviter caudatae. Stylus simplex minute bilobus. Ovarium abortivum anguste oblongum glabrum bivenosum.

Type: South Africa, Cape Prov., Bredasdorp Div., 0.5mi. E of Cape Agulhas, limestone hill ridges, 18 ix 1962, B. Nordenstam 1461 (holo. S!; iso. NBG!, PRE!). 
Shrub $0.5-1 \mathrm{~m}$ high, little to moderately branched. Stems and branches loosely white-woolly, glabrescent. Leaves alternate, closely set, erecto-patent to subappressed, sessile, entire, elliptic-ovate to oblong-lanceolate (or even oblanceolate), $2-5 \times 0.5-2 \mathrm{~cm}$, coriaceous, with distinct midrib and $2-4$ faint parallel veins, somewhat woolly especially when young and towards base, glabrescent; margins distinct, cartilaginous-scabrid, initially somewhat dark, turning whitish; midrib cartilaginousscabrid; apex acute to shortly mucronate; base semi-amplexicaul. Capitula terminal, solitary, sessile or subsessile, heterogamous, conspicuously radiate. Involucre hemispherical, c. $2-3 \mathrm{~cm}$ in diam., white-woolly especially at base; involucral bracts $14-17$, \pm biseriate, narrowly oblong-lanceolate, $10-20 \times 2-5 \mathrm{~mm}$, herbaceous, flat, faintly reticulate-veined, laxly white-woolly, acute to acuminate with somewhat purplish tips and scabrid margins. Receptacle somewhat convex, naked, glabrous. Rayflowers 11-20, female; limb narrowly oblong to oblanceolate, 20-35 $\times 2.5-6 \mathrm{~mm}$, distinctly 4(-7)-veined, deep yellow to orange, reddish or maroon on reverse, minutely 3-fid at apex, glabrous; tube short, 1-3mm long, somewhat compressed. Style branches linear, 1-1.5mm long, obtuse, with marginal stigmatic lines. Cypselas ellipsoid-obovoid, $5-5.5 \times 3 \mathrm{~mm}$, glabrous, light brown or straw-coloured, somewhat constricted towards base, with 5 or 6 low ridges widest at base; pappus absent. Discflowers numerous (c.100), functionally male. Corolla tubular, 5-6mm long, gradually widening upwards, 5-lobed, with sparse, short-stalked patent glands; lobes narrowly ovate, $1.5-1.8 \mathrm{~mm}$ long, acute, without midvein but with lateral marginal veins joining at sinuses and continuing down corolla. Anthers c.2mm long, shortly caudate, apical appendage triangular-ovate. Style sterile, simple, obtuse, minutely papillate, shortly bilobed. Ovary narrowly oblong to linear, glabrous, 2-veined.

Additional specimens examined. South Africa, CAPe Prov. (Bredasdorp District), Farm Awila, limestone, 9 ix 1976, H. Wild 8022 (E photocopy, SRGH); 3419 DA, Klein Hagelkraal E of Pearly Beach, S slope, 100ft., 10 iv 1979, L. Hugo 1740 (NBG); 3419 DA, Hagelkraal, Pearly Beach, limestone ridge, steep slopes, SE aspect, 12 ix 1981, L. Hugo 2666 (NBG, PRE); 3419 DA, limestone hills above Korsika, 170m, 29 iv 1981, C.J. Burgers 2694 (NBG); 3419 AD, limestone scree slopes and ridges, N slope, 600-700ft., 31 x 1986, C.H. Stirton 11359 (NBG).

Flowering period. September-April.

Derivation. Named for its location at the southernmost point of Africa.

Distribution and ecology. Restricted to coastal and lowland limestone in the vicinity of Cape Agulhas, the southernmost tip of Africa. The population found by me in 1962 was quite small and limited to a low limestone ridge in a low-growing fynbos community with Aspalathus incurvifolia Vogel ex Walp., Erica longifolia Donn, Felicia nordenstamii Grau (type locality), Pelargonium betulinum Aiton, Adenandra obtusata Sond. and species of Protea, Mimetes and Gladiolus.

Conservation status. A local and apparently rare species endemic to lowland limestone. It is nowhere abundant and possibly threatened or endangered. An 
attempt in 2002 to find it again in the type locality was unsuccessful (Alan Wood, pers. comm.).

Osteospermum australe is a small shrub with closely set leaves, which are entire with distinct cartilaginous and scabrid margins. The upper leaves, particularly on flowering branches, are imbricate and distinctly margined. The large and more or less sessile capitula have numerous conspicuous rays and the involucre is at least partly covered by the dark-margined upper leaves. There is some variation in size of leaves and capitula; the specimens from Pearly Beach are larger than the type collection from Cape Agulhas, but there is no doubt that they are conspecific (Fig. 1A,B).

Osteospermum australe is a very distinct species apparently without close relatives. Osteospermum imbricatum L., as the name implies, also has imbricate leaves which are, however, much smaller, and its capitula are small and distinctly pedunculate. Osteospermum rotundifolium (DC.) T. Norl. is very different in leaf shape and synflorescence, with several small pedunculate capitula.

Osteospermum burttianum B. Nord., sp. nov. (sect. Polygalina). Fig. 2.

Frutex ramosus compactus rotundatus $0.3-1 \mathrm{~m}$ altus et latus; rami glabri dense foliati. Folia alterna subcoriacea glabra sessilia semiamplexicaulia integerrima anguste oblonga usque oblanceolata vel spathulata $2-8 \times 0.5-2 \mathrm{~cm}$ obtuse apiculata margine scabrida nervo medio instructa. Capitula in caule et ramis terminalia solitaria pedunculata, pedunculi breviter fusco-hirtelli $3-6 \mathrm{~cm}$ longi bracteis paucis instructi. Involucri bracteae 8-13 subuniseriatae vel biseriatae anguste ellipticooblongae $8-10 \times 3-4 \mathrm{~mm}$ herbaceae breviter glandulosae acutae-acuminatae. Flores radii feminei $8-11$, ligulae flavae anguste elliptico-oblongae. Cypselae oblongoobovoideae $5.5-6.5 \times 2-2.5 \mathrm{~mm}$ glabrae in sicco fuscoatrae obscure costatae. Flores disci numerosi pseudohermaphroditi q-steriles; corolla flava quinquelobata sparse glandulosa vel glabra. Antherae caudatae. Stylus simplex apice minute bilobus. Ovarium abortivum anguste oblongum glabrum bivenosum.

Type: South Africa, Cape Prov., Heidelberg Distr., 3320 DD, Goedehoop Peak (Horingberg), Langeberg E of Lemonshoek, S slopes, 3500-4000ft., 31 xii 1978, E. Esterhuysen 35154 (holo. S!; iso. BOL!, E, K!, PRE!, S!).

Much-branched compact rounded or low-growing spreading shrub or shrublet $0.3-1 \mathrm{~m}$ high and wide. Stems and branches erect to erecto-patent, glabrous, densely foliate. Leaves alternate, closely set, sessile, entire, narrowly oblong-oblanceolate or spathulate, $2-8 \times 0.5-2 \mathrm{~cm}$, glabrous, somewhat coriaceous, with distinct midrib, flat; base semiamplexicaul, margins minutely hirsute-serrulate or scabrid with brownish small hairs, apex rounded-obtuse and apiculate-mucronate. Capitula solitary, pedunculate, heterogamous; peduncles $3-10 \mathrm{~cm}$ long, with 1-3 bract-like reduced leaves, fusco-hirsute with stiff short hairs. Involucre $1-1.5 \mathrm{~cm}$ in diameter. Involucral bracts \pm uniseriate to biseriate, 8-13, narrowly elliptic-oblong, $8-10 \times 3-4 \mathrm{~mm}$, herbaceous, reticulate-veined, with short dark-tipped glandular hairs, acute to acuminate. Receptacle convex, naked, glabrous. Ray-flowers female, 8-11; tube 


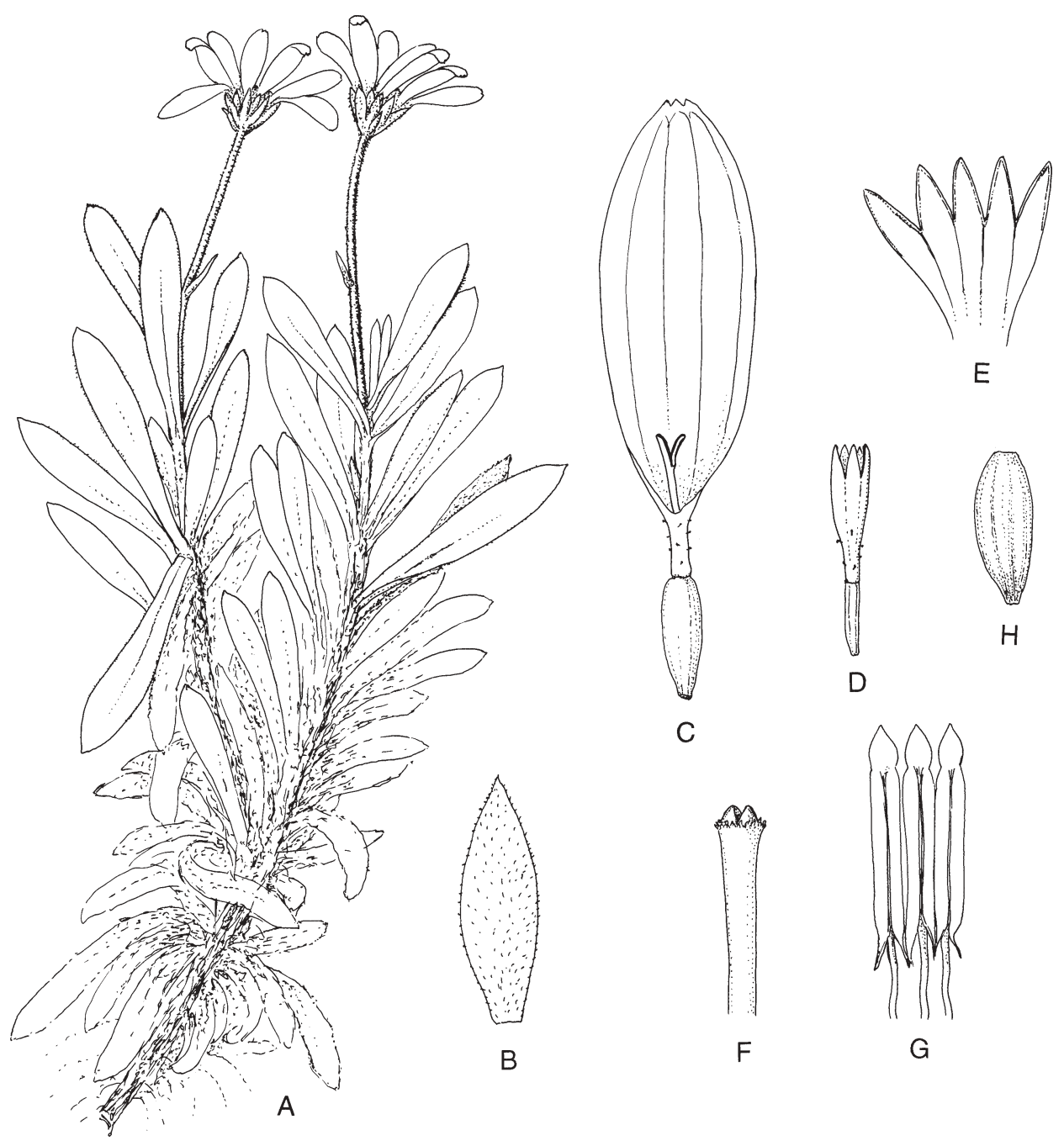

FIG. 2. Osteospermum burttianum. A, habit $(\times 1 / 2)$; B, involucral bract $(\times 3)$; , ray-flower $(\times 3)$; D, disc-flower $(\times 3)$; E, corolla of disc-flower opened $(\times 6)$; F, style of disc-flower $(\times 12)$; G, anthers $(\times 12)$; H, cypsela $(\times 3)$. (Esterhuysen 35154 in $\mathrm{S}$, holotype). Drawn by the author.

1-3mm long, sparsely glandular with multicellular stalked glands; lamina narrowly elliptic-oblong, yellow, 12-18 ×4-6mm wide, 4-veined, apically 3-fid. Style branches narrowly oblong to linear, $0.8-1.5 \mathrm{~mm}$ long, obtuse-subacute, with distinct marginal stigmatic lines. Cypselas oblong-obovoid, $5.5-6.5 \times 2-2.5 \mathrm{~mm}$, narrowed to base, smooth, glabrous, (probably with thin fleshy exocarp when fresh), drying purplishblack, obscurely ridged with longitudinal low blunt ridges, pappus absent. Discflowers functionally male, numerous. Corolla yellow, $4.5-5.5 \mathrm{~mm}$ long, tubular below and with a narrowly campanulate 5-lobed limb, sparsely glandular or glabrous; 
lobes ovate-oblong, $1.5-1.8 \mathrm{~mm}$ long, apically crested and acute, without midvein, with lateral marginal veins connecting at the sinuses and continuing down the corolla. Anthers $2 \mathrm{~mm}$ long, base caudate, apical appendage triangular-ovate. Style simple, sterile, apically tipped with a shortly bilobed obtuse cone surrounded by a fringe of short pili. Ovary narrowly oblong, 1.5-2.5mm long, glabrous, 2-veined.

Additional specimens examined. South Africa, CApe Prov. Swellendam Div., S slopes of Naauwkransberg in the Langebergen near Heidelberg, 3000-4000ft., 28 iii 1948, E. Esterhuysen 14426 (BOL, K); Warmwaterberg 3320 DD, Langeberg East MCA, Horingberg, vertical slope, S aspect, 1000-1300m, 8 i 1987, T.J. van der Merwe 175 (NBG, PRE); 3320 CD, Langeberg, trail 15F in Protea Valley between Warmwaternek and Protea Valley hut, S slope of second mountain range in deep kloof, 1000m, 3 v 1987, J.L. du Plessis 22 (NBG).

Flowering period. December-May (August).

Derivation. Named for Mr B.L. (Bill) Burtt in recognition of his outstanding contribution to the knowledge of the Compositae and to South African phytogeography.

Distribution and ecology. Apparently endemic to the Langebergen near Heidelberg, an area recognized as a local centre (or subcentre) of endemism within the Cape Floristic Region (Weimarck, 1941; Goldblatt \& Manning, 2000; van Wyk \& Smith, 2001). Osteospermum burtianum grows as a compact or somewhat diffuse rounded shrub on steep slopes and south-facing cliffs at altitudes above $1000 \mathrm{~m}$. It occurs in mountain fynbos with Restio Rottb., etc. on sandstone derived soil (TMS).

Conservation status. A species with restricted distribution in a mountainous habitat. It may be safe in some steep cliff habitats, but might be regarded as vulnerable because of its limited distribution and proximity to some popular walking trails and hiking areas.

Osteospermum burttianum is related to $O$. polygaloides L., which though variable, is never as large-leaved as the new species and has a different habit, not being cushionshaped. The capitula of $O$. polygaloides are distinctly smaller with less conspicuous rays.

\section{ACKNOWLEDGEMENTS}

I wish to thank Nicholas Hind and Lawrie Springate for useful reviewing and Crinan Alexander for pertinent editorial comments.

\section{REFERENCES}

Goldblatt, P. \& Manning, J. C. (2000). Cape plants: A conspectus of the Cape flora of South Africa. Strelitzia 9. National Botanical Institute and Missouri Botanical Garden.

Nordenstam, B. (1994a). Tribe Calenduleae. In: Bremer, K. (ed.) Asteraceae: Cladistics and Classification, pp. 365-376. Portland, Oregon: Timber Press. 
Nordenstam, B. (1994b). New combinations in the Calenduleae. Compositae Newsletter 25: 46-49.

Nordenstam, B. (1996). Recent revision of Senecioneae and Calenduleae systematics. In: Hind, D. J. N. \& Beentue, H. (eds) Compositae Systematics: Proceedings of the International Compositae Conference, Kew 1994, pp. 591-596. Royal Botanic Gardens, Kew.

Nor Lindi, T. (1943). Studies in the Calenduleae. I. Monograph of the genera Dimorphotheca, Castalis, Osteospermum, Gibbaria and Chrysanthemoides. Lund: Gleerup. Norlindh, T. (1960). Additions to the monograph on Osteospermum. Bot. Not. 113 : 385-399.

Norlindh, T. (1977). Calenduleae - systematic review. In: Heywood, V. H., Harborne, J. B. \& Turner, B. L. (eds) The Biology and Chemistry of the Compositae II, pp. 961-987. London, New York, San Francisco: Academic Press.

Weimarck, H. (1941). Phytogeographical Groups, Centres and Intervals within the Cape Flora. Lunds Univ. Arsskr. Avd. 2, 37: 1-143.

Wood, A. R. \& Nordenstam, B. (2003). An interesting new species of Osteospermum (Asteraceae-Calenduleae) from the western Cape Province, South Africa, providing a link to the genus Chrysanthemoides. S. African J. Bot. 69(4): 572-578.

van Wyk, A. E. \& Smith, G. F. (2001). Regions of Floristic Endemism in Southern Africa. Hatfield, South Africa: Umdaus Press.

An invited contribution to the Festschrift for B.L. Burtt's ninetieth birthday 